„Przekłady Literatur Słowiańskich”. T. 9, cz. 3

ISSN 2353-9763 (wersja elektroniczna)

DOI 10.31261/PLS.2019.09.03.06

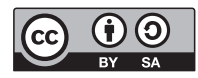

\title{
Bibliografia przekładów literatury polskiej w Chorwacji w 2017 roku
}

\section{The Bibliography of Translations of Polish Literature in Croatia in 2017}

\section{Petra Gverić Katana}

iD https://orcid.org/0000-0002-0580-7669

JUSTUS LIEBIG UNIVERSITY IN GIESSEN

petra.gveric@gmail.com 


\section{Publikacje książkowe}

1. Bandrowski Jerzy: Wściekłe psy / Bijesni psi. Prev. Adrian C vit a n o vi ć. Zagreb, DAF, 2017, 363 s. [proza].

2. Chutnik Sylwia: Kieszonkowy atlas kobiet / Džepni atlas žena. Prev. Emilio N u i ć. Zagreb, Hena com, 2017, 228 s. [proza].

3. Klicka Barbara: Bankiet i skóra / Banket $i$ koža. Prev. Đurđica Čili ć Škelj o. Zagreb, SKUD „Ivan Goran Kovačić“, 2017, 48 s. [poezja].

4. Kolbe Maksymilian: Pisma / Spisi. Prev. Jelena Vuković et al. Zagreb, Hrvatska provincija sv. Jeronima franjevaca konventualaca; Veritas, 2017 [proza].

5. Koneczny Feliks: O wielości cywilizacji / Raznolikost civilizacija. Prev. Antonio A k m a d ža. Zagreb, Repressija, 2017, 332 s. [proza].

6. Pelanowski Augustyn: Nie ma już czasu / Nema više vremena! Prev. Melita M e s a r i ć et al. Koprivnica, Figulus, 2017, 288 s. [proza].

7. Piątkowska Irena: Piegowate opowiadania / Pjegaste priče. Prev. Adam A g i č i ć. Zagreb, Srednja Europa, 2017, 95 s. [proza].

8. Pilch Jerzy: Pod mocnym aniołem / K pijanom anđelu. Prev. Emilio N u i ć. Zagreb, Hena com, 2017, 216 s. [proza].

9. Stasiuk Andrzej: Wschód / Istok.

Prev. Siniša K a s u m o vi ć. Zagreb, Fraktura, 2017, 227 s. [proza].

10. Tyrmand Leopold: Cywilizacja komunizmu / Civilizacija komunizma. Prev. Adrian C v i t a n o v i ć. Zagreb, Disput, Hrvatsko filološko društvo, 2017, 314 s. [proza].

11. Tuwim Julian: Pan Maluśkiewicz i wieloryb / Gospodin Mališkijević Malicki i kit.

Prev. Enes K i š e v i ć. Zagreb, Ibis grafika, 2017, 16 s. [poezja].

12. Wojtyła Karol: Fenomeni Wojtyline iznimnosti.

Priredio i prev. Pero M i o č. Vodice, Z. Vampovac, 2017, 161 s. [poezja].

\section{Publikacje w czasopismach}

1. „Dubrovnik” 2017, br. 1 .

Wisława Szymborska

Nedolično i vrijedno spomena*.

Prev. Stanislava Nik olić A ras, s. 78.

Nic darowane / Ništa darovano.

Prev. Pero Mi o č, s. 78 [poezja]. 
2. „Hrvatsko slovo” 2017, br. 1142.

\section{Różewicz Tadeusz}

Maison de Retraite / Maison de Retraite

Whotelu / U hotelu

Z ust do ust / Od usta do usta.

Prev. Pero Mi o č, s. 24 [poezja].

3. „Hrvatsko slovo” 2017, br. 1144.

\section{Różewicz Tadeusz}

Drugie poważne ostrzeżenie / Drugo ozbiljno upozorenje

Widziałem go / Vidio sam ga

Zamračenje svjetla*.

Prev. Pero M i o č, s. 24 [poezja].

4. „Hrvatsko slovo” 2017, br. 1147.

\section{Różewicz Tadeusz}

Moda / Moda

Recycling / Reciklaža

Totentanz - wierszyk barokowy / Totentanz - barokna pjesmica.

Prev. Pero Mi o č, s. 24 [poezja].

5. „Hrvatsko slovo” 2017, br. 1149.

\section{Kornhauser Julian}

Dzieci / Djeca

Leđa*

Na imanju na Dżusatyńkom kordonu*

Śpi ciemna dziewczynka / Spava tužna djevojčica

Vražje kolo*

Wyciagnięta ręka / Ispružena ruka.

Prev. Pero M i o č, s. 24 [poezja].

6. „Hrvatsko slovo” 2017, br. 1151.

\section{Lipska Ewa}

A mi smo trčali*

Dom spokojnej młodości / Dom spokojne mladosti

Moja siostra / Moja sestra

Stół rodzinny / Obiteljski stol.

Prev. Pero Mi o č, s. 24 [poezja].

7. „Hrvatsko slovo” 2017, br. 1153.

\section{Lipska Ewa}

Dom dziecka / Dječji dom

$\mathrm{My} / \mathrm{Mi}$

O czym myśli dziewczynka na lekcji gramatyki języka polskiego /

O čemu razmišlja djevojčica na satu gramatike poljskog jezika 
Zaręczyny / Zaruke.

8. „Hrvatsko slovo” 2017, br. 1157.

\section{Lipska Ewa}

\section{Bezpieczeństwo / Sigurnost}

Dom spokojnej starości / Dom spokojne starosti

Dzieci / Djeca

Mała dziewczynka podgląda naród / Mala djevojčica uhodi narod

Z listu / Iz pisma.

Prev. Pero Mi o č, s. 24 [poezja].

9. „Hrvatsko slovo” 2017, br. 1163.

\section{Lipska Ewa}

Chwila / Trenutak

Dogadaji*

Jeśli istnieje Bóg / Ako postoji Bog

Ostrzė̇enie / Upozorenje

Siedemnaście rudych wiewiórek / Sedamnaest riđih vjeverica

Takie czasy / Takva su vremena

Z listu / Iz pisma (II).

Prev. Pero Mi o č, s. 24 [poezja].

10. „Hrvatsko slovo” 2017, br. 1165.

\section{Kornhauser Julian}

Cień / Sjena

Już nic / Više ničega nema

Kamyk i cień / Kamenčić i sjena

Kutija $^{*}$

Ołówek / Olovka.

Prev. Pero M i o č, s. 24 [poezja].

11. „Hrvatsko slovo” 2017, br. 1169.

\section{Kornhauser Julian}

Bar micwah / Bar Micva

Bat / Bič

Kafka / Kafka

Wiersz o zabiciu doktora Kahany /

Pjesma o ubojstvu doktora Kahane

Żydowska piosenka / Židovska pjesma.

Prev. Pero Mi o č, s. 24 [poezja].

12. „Hrvatsko slovo” 2017, br. 1173.

\section{Kornhauser Julian}

Bedemi* 
Naród / Narod

Piękno / Ljepota

Ti na nogostupu*

Wierność / Vjernost.

Prev. Pero Mi o č, s. 24 [poezja].

13. „Hrvatsko slovo” 2017, br. 1177.

\section{Kornhauser Julian}

List do Kazimierza Biculewicza / Pismo Kazimierzu Biculewiczu

Nevolja s postojanjem*

Wieczna przyszłość / Stalna budućnost.

Prev. Pero M i o č, s. 24 [poezja].

14. „Hrvatsko slovo” 2017, br. 1183.

\section{Kornhauser Julian}

Dlaczego nas? / Zašto nas?

Szczelina / Pukotina.

Prev. Pero Mi o č, s. 24 [poezja].

15. „Sic” 2017, br. 2.

\section{Nowicka Bronka}

Firanka / Zavjesa

Łyżeczka / Žličica

Skóra / Koža.

Prev. Đurđica Čil i ć, s. 1-3 [poezja].

16. „Tema” 2017, br. 1-2-3.

\section{Nowicka Bronka}

Poduszka do igiet / Jastučić za igle.

Prev. Đurđica Či l i ć, s. 121 [poezja].

PETRA GVERIĆ KATANA | mgr filologii chorwackiej oraz filologii polskiej. Lektor języka polskiego (do 2018 roku w Instytucie Filologii Słowiańskiej Uniwersytetu Śląskiego w Katowicach, obecnie na Uniwersytecie Justusa Liebiga w Gießen w Niemczech). Jej zainteresowania naukowe skupiają się wokół glottodydaktyki, przekładoznawstwa, komparatystyki i teatrologii. 